\title{
A non invasive method for the study of the sex-ratio in a population of Myotis myotis and Myotis blythii (Chiroptera) in Piedmont region (Italy)
}

\author{
F. Borghese, E. Chiaramello,A.Viglino, P. Culasso, M. Del Pero, P. Cervella, G. Sella
}

Dipartimento di Biologia Animale e dell'Uomo - Università di Torino - Via Accademia Albertina I3 - 10123 - Torino - ITALY

KEYWORDS: bats, genetic markers, population structure

\section{Abstract}

This study contributes to the knowledge of demographic structures of the two sympatric, sister species Myotis myotis and Myotis blythii (Chiroptera).The sites investigated were the Abbazia di Santa Maria in Staffarda and the Castello Ducale in Agliè, known to accommodate the larger Myotis colonies in North-Western Italy. Samplings were conducted in summer 2006. During this season tens to hundreds of females gather together to form the so called nurseries, composed by mothers with their litters. With the end of summer, males reach the nurseries for mating.

Since these species are severely endangered of extinction, we adopted a non-invasive, opportunistic sampling method based on collection of feces, although tissues from died specimens were harvested as a control of the method. Total DNAs extracted from stool samples were amplified using a pair of specific primers for the DBY8 locus on the $Y$ chromosome, along with an internal control shared by both sexes.

The results showed that the colony located in the Abbazia di Staffarda is a typical nursery, while in the Castello di Agliè the situation is composite, because sorting of individuals describes this latter community as both a nursery and a reproductive colony.

\section{Introduction}

The Order Chiroptera represents over one quarter of the world's mammalian diversity, but is one of the least understood among terrestrial mammals; even the taxonomy of the Order is debated. With about 103 species currently described, the genus Myotis (Vespertilionidae) is a very successful group of bats. They have been radiating for at least the last 30 Myr (Quinet, 1965), with a burst of diversification during the late Miocene/early Pliocene; this most recent radiation has given Myotis a nearly global distribution tied in with remarkable eco-morphological diversification (Nowak, 1991).

Phylogenetic reconstructions based on molecular data have shown recurrent morphological convergence during evolution of the genus Myotis. Species or groups of species with similar feeding strategies evolved independently several times, with substantial similarities in external morphology and eco-etological features. This is especially true for the greater mouse-eared bat (Myotis myotis) and the lesser mouse-eared bat (Myotis blythii). These two sister species are difficult to distinguish morphologically, although they differ in their ecology and physiology. However, they occur in sympatry over wide areas of Southern and Central Europe and often form mixed roosting groups (Arlettaz et al., 2001).

Alike most of the Chiroptera species, also M. myotis and $M$. blythii show a peculiar social organisation: size and composition of groups may vary according to the species, but typically these groups are constituted by females with their newborn and subadult offspring who establish stable colonies (nurseries). Males, as a rule, leave the maternal colony when adulthood is reached, living then in solitude or in small groups; isolated males can be tolerated in a nursery, provided they roost at some distance apart from the females. During the reproductive season (in the midsummer in N-W ltaly) males get access to the nurseries, where matings take place. At the end of summer all the individuals migrate to the "hibernacula", protected shelters where they spend the winter.

The high risk of extinction to which natural bat populations are prone makes it mandatory a careful knowledge of their population structures and dynamics. The precise description of the structures of natural bat populations at the genetic level is the precondition for the institution of accurate management and conservation programs. Here, we report a genetic analysis performed on samples collected during the summer 2006 in the two most important nurseries of $M$. myotis and M. blythii in NorthWestern Italy. The first inhabits a vast room in the basement of the Abbazia di Santa Maria (Staffarda, Cuneo), while the second is settled in the cellars of the Castello Ducale (Agliè, Torino). 


\section{Materials and Methods Sampling}

Fecal samples were harvested in the Castello di Agliè colony, while tissutal samples from carcasses were gathered in the Abbazia di Staffarda (Figure I).

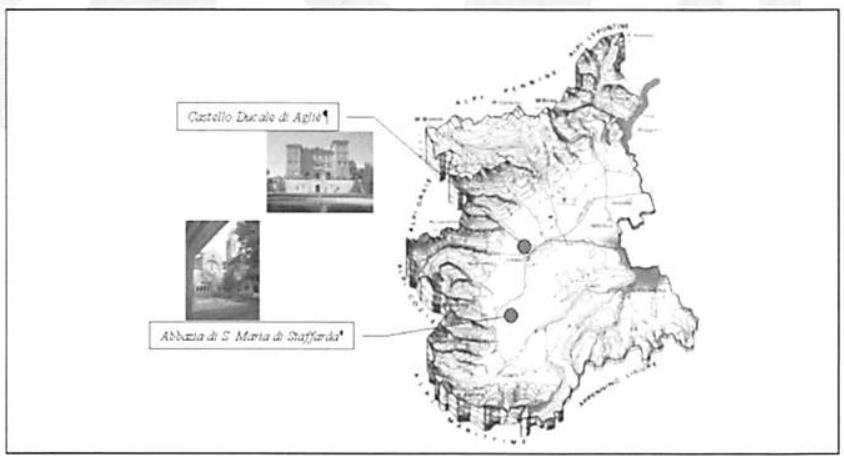

Figure I - location of the two sampled populations in Piedmont (North-Western Italy).

Feces were harvested by covering the floor of the rooms were bats roosted with several sheets of newspapers. This operation was carried out in the evening, after all the individuals had left the room to search for food. In the morning, late after the homecoming of the colony, the sheets were removed; the fecal pellets were catalogued, placed into Eppendorf tubes with a grain of silica to adsorb the moisture, and stored in a freezer on arrival to the lab. Several carcasses of juveniles occasionally dropped down from their mother's chest were also collected. Carcasses were put in ice and then stored at $-30^{\circ} \mathrm{C}$; tissutal samples were minced and submerged in lysis solution (Laird et al., I99I) until extraction.

\section{DNA extraction and PCR amplification}

Total DNAs were extracted from the carcasses according to standard methods (Laird et al., 1991). For DNA extraction from the feces the Qiagen Stool Kit (QIAGEN, Inc.) was used according to the manufacturer's instructions. For PCR analysis, a segment of the $8^{\text {th }}$ intron of the DBY gene, located on the $Y$ chromosome (Hellborg and Ellegren, 2003), was coamplified along with a segment of the mitochondrial control region (Castella et al., 200I).Variable amounts of genomic DNA, depending on the source and ranging from approximately $20 \mathrm{ng}$ to few picograms, were amplified with specific primers in the following conditions: Ix buffer / $2.5 \mathrm{mM} \mathrm{MgCl} / 2$ 0,25 $\mu$ M each primer / $0.2 \mathrm{mM}$ dNTPs / 0.5 u Taq-DNA polymerase (Fisher) in a final volume of $20 \mu \mathrm{L}$. After an initial denaturation step ( $3 \mathrm{~min}$. at $\left.95^{\circ} \mathrm{C}\right)$, cycling profile was: $45^{\prime \prime}$ at $94^{\circ} / 45^{\prime \prime}$ at $50^{\circ} / \mathrm{I}$ ' at $72^{\circ}$ repeated for $30-40$ cycles (for tissue samples) or 50 cycles (for fecal samples), followed by a final extension step of $7^{\prime}$ at $72^{\circ}$. Reactions were then electrophoresed and photographed under UV light.

\section{Data analysis}

Specimens were scored as males if two bands of $200 \mathrm{bp}$ and $307 \mathrm{bp}$, corresponding to the $Y$ chromosome-specific DBY and mitochondrial control region amplicons, respectively, were visible; in the other case, in presence of a single band corresponding to the 307 bp product, they were considered as derived from a female (see Figure 2).

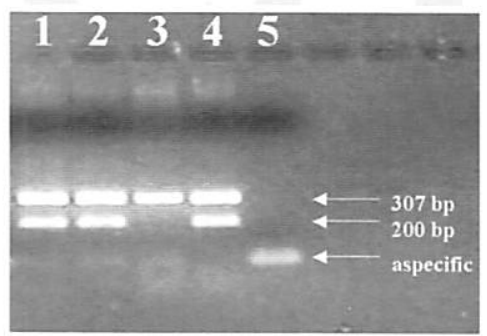

Figure 2 - Agarose gel showing an example of PCR amplification of segments from locus DBY8 (200 bp) and mitochondrial control region (307 bp). Lanes 1-4 show specific bands expected for males (lanes I, 2, 4) or females (lane 3); lane 5 corresponds to the negative control. Specimens presenting the $200 \mathrm{bp}$ amplicon, derived from the $8^{\text {th }}$ intron of the $D B Y$ gene, were scored as males, while those lacking this band were considered females.

\section{Results and Discussion}

\section{Abbazia di Staffarda}

Sampling was carried out in May-June 2006, and consisted in harvesting 46 carcasses of newborn and juvenile specimens accidentally died. This colony is a typical nursery composed by 600 to 1000 females with their offsprings. Results summarised in Table I confirm the I:I sex ratio at birth. A nursery can be considered the most delicate and vulnerable facet of natural bat populations; mortality principally affects newborn offspring, more exposed to perturbing sollicitations.

\begin{tabular}{|c|c|c|}
\hline \multicolumn{3}{|c|}{ Abbazia di Staffarda } \\
\hline $\begin{array}{l}\text { Total number } \\
\text { of specimens }\end{array}$ & Males & Females \\
\hline 46 & 24 & 22 \\
\hline
\end{tabular}

Table I - results of analysis performed on Staffarda samples

\section{Castello Ducale di Agliè}

Sampling was carried out during a single day in early September 2006. A scheme of the sampling area is shown in Figure 3. In the first room (A) the largest part of the colony nested: bats were distributed in a bunch of about 200 individuals (AI) suspended to the ceiling, and in two other groups (A2 and $A 3$ ) for a total of 24 individuals hanged in niches of the wall. In a large room (B), 8 individuals were scattered in 3 major groups (BI, B2, B3). In the last small room $(C)$ only 3 individuals were found. 


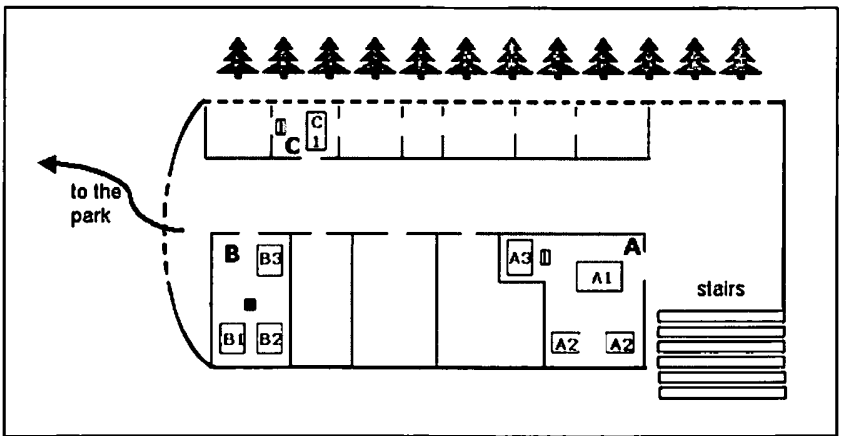

Figure 3 - Sketch plan (not to scale) of the cellars at the Castello Ducale di Agliè. $A, B$ and $C$ indicate rooms were bats were found and sampled. Pine trees depict the park surrounding the castle. Labeled boxes represent the arrangement of bats whose feces were harvested.

Results of sampling and sex determination are summarised in Table 2. In this case, sampling was accomplished during a less critical period of bats' life cycle. The results describe room $A$ as a typical nursery, with a sex-ratio considerably biased towards the females. Room B could represent a mating arena, in which males meet up fertile females, giving them the opportunity to choose for mating. Room C could represent a small settlement occasionally attended by few females roosting together $(\mathrm{Cl})$. We interpret this situation as transitory from a typical summer nursery to a dynamic mating arena.

\begin{tabular}{|l|c|c|c|}
\hline \multicolumn{4}{|c|}{ Castello di Agliè } \\
\hline Room & A & B & C \\
\hline Number of & & & \\
\hline $\begin{array}{l}\text { fecal samples } \\
\text { picked }\end{array}$ & 34 & 8 & 3 \\
\hline Males & 3 & 4 & 0 \\
\hline Females & 31 & 4 & 3 \\
\hline
\end{tabular}

Table 2 - results of analysis performed on Agliè samples

\section{Conclusions}

With the present research we assessed the feasibility of a molecular genetic study on Myotis natural populations taking advantage from a non invasive sampling method. Our preliminary results describe the organisation of the two principal Myotis populations in North-Western Italy during two crucial periods of the year. More detailed genetic inspection will be required to fully describe the population structures in a given site and/or seasonal period. However, the minimal disturbance brought to the animals and the reliability of genetic analyses make our procedure appropriate and promising for more comprehensive research projects.

\section{Acknowledgments}

This work was supported by funds from "Bando Regionale sulla Ricerca Scientifica Applicata 2004 - Regione Piemonte" to G.S.

\section{References}

Arlettaz R., Christe P., Lugon A., Perri, N. \& Vogel P. 200I. Food availability dictates the timing of parturition in insectivorous mouse-eared bats. Oikos 95: 105-111.

Castella V., Ruedi M., Excoffier L. 200I. Contrasted patterns of mitochondrial and nuclear structure among nursery colonies of the bat Myotis miotis. J. Evol. Biol. 14: 708-720.

Hellborg L., Ellegren H., 2003.Y chromosome conserved anchored tagged sequences (YCATS) for the analysis of mammalian male-specific DNA. Molecular Ecology, 12: 283-291.

Laird PW., Zijderveld A., Linders K., Rudnicki M.A., Jaenisch R., Berns A. 1991. Simplified mammalian DNA isolation procedure. Nuclei Acid Research. 19 (15): 4293.

Nowak RM. 1991. Walker's mammals of the World. Baltimore (MD): Johns Hopkins University Press.

Quinet GE. 1965. Myotis misonnei. chiroptere de l'Oligocene de Hoogbutsel. Bull Inst R Sci Nat Belg. 41:1-1 I.

Taberlet P.,Waits L., Luikart G. 1999. Noninvasive genetic sampling: look before you leap. Trends in Ecology and Evolution, 14: 323-327. 